\title{
WHEN SACRED SITES BECOME SYMBOLS OF NATIONHOOD*
}

Turkestan is a place of pilgrimage for Muslims in southern Kazakhstan close to the border with Uzbekistan. It is a few hours by car from Shymkent, the most important city in southern Kazakhstan. The sacred site is actually just outside of the small city of Turkestan and is an impressive complex of mausoleums, graves and mosques. A museum of Kazakh 'ethno-history' and guest houses for pilgrims complete the site. The buildings - apart from some mausoleums and grand Muslim tombs - are new and in excellent condition. Clean, well swept pavements connect the different buildings distributed around the compounds. Trees are planted to provide protection from the hot Central Asian sun and the pathways are lined with benches. Numerous memorial buildings are clearly indicated and signs along the pavements usher visitors on their way. Later, examining the photos I took on site, I discovered that the signs were only in Kazakh and English. Russian was totally absent. I have visited the site twice, in April 2016 and September 2018, and was involved in discussions with my colleagues, students and informants about the meaning of Turkestan for Kazakhs. It must be noted that there is no one coherent interpretation of this topic and my discussion partners' positions differed according to their regional origin, occupation, age and sex.

The centre of the pilgrimage complex is the mausoleum of Sufi poet Kozha (Hodja) Akhmet Yasaui, which he shares with Abilai Khan, a Kazakh khan in the 18th century. Around his resting place stand a few mausoleums of Kazakh khans. Their mausoleums are also impressive, although none is as splendid as Kozha Akhmet Yasaui's. The main pilgrimage place, it is a huge mosque that includes several prayer rooms and a kitchen where historically food for pilgrims was cooked. The building functions as a pilgrimage site combined with a museum. Kozha Akmet was born at the beginning of the 12th century BC and died in the second half of the century in Turkestan, and in those times was called Yasawi or Yasau. He was the founder of one of the three most influential Central Asian Sufi orders - Yasawiyya, who included shamanic rituals into their practices (Roy 2000: 147). Kozha Akhmet Yasaui is considered a saint by most Central Asian Turkic peoples and Kazakhs are proud that Turkestan is currently an international pilgrimage site. This assumption is confirmed by a sign at the entrance of his mausoleum with Kazakh and Turkish flags announcing that these states cooperated in establishing the 'visual history room' within the mausoleum. There is also a plate announcing that some renovations were carried out as a joint project between Azerbaijan and Kazakhstan. In the room is a plate with words of the President of the Republic of Kazakhstan saying that without Islam there would be no Kazakhs.

Despite the claim that Turkestan is an international pilgrimage site for (mainly) Central Asian Turkic people, for Kazakhs this place is a national treasure. The mausoleums of the Kazakh khans reflect the political significance of the site. This is also symbolised by a small monument in honour of 550 years of Kazakh statehood at the entrance of the pilgrimage site. Many Kazakhs still resent the words of Russian president Vladimir Putin,

\footnotetext{
* This research was supported by institutional research funding grant IUT34-32 Cultural Heritage As a Socio-cultural Resource and Contested Field from the Estonian Ministry of Education and Research.
} 
who said in 2014 that "Kazakhs had never had statehood" (Osharov 2014), and were greatly offended when he repeated them in 2018. At the entrance of the complex is a huge marble wall where all Kazakh khans and sultans are listed chronologically, a smaller version of which hangs in the mausoleum. First on the list is Kozha Akhmet Yasaui, so it becomes clear that he is not only a spiritual figure but someone who symbolises the very beginning of Kazakh statehood.

Without doubt the Turkestan pilgrimage site symbolises the interconnection between the politics, religion and identity of the Kazakh people. Academically, it is assumed that Kazakh ethnic identity is strongly connected with Islam and that the independence of Kazakhstan gave a free reign to a religion previously oppressed during the Soviet period (Hiro 1994; Hann and Pelkmans 2009). Historically, at the beginning of the 1990s the Republic of Kazakhstan was seen as a state of and for Kazakhs, a status that was slowly reshaped by Nursultan Nazarbayev into a multi-ethnic state. During the early 1990s Nazarbayev tried to emphasise the Islamic component of Kazakh national identity, only to give it up later for the concept of the republic as a secular state (Dave 2007; Aitken 2009; Cummings 2009). Therefore, Turkestan's official status is site of national heritage. It is a museum complex not a destination for pilgrimage. The underlying line is, however, that this place is linked to Kazakh statehood and Turkic heritage and symbolises Kazakhstan's membership of the Islamic world. It seems to me that the state emphasises this line surreptitiously in order to avoid ethnic and confessional tension with Russians and Russified non-Muslims like Ukrainians, Germans or Belorussians.

As researchers suggest, in Central Asian states there is a certain discrepancy between the ethnic and the national identity (see Roy 2000: 177). For most titular ethnic groups this is one and the same thing and they consider the state 'their own'. This assumption is in all cases legitimised with the situation that the language of the titular ethnic group is simultaneously the only or first national language. And here Kazakhstan is no exception. Notwithstanding the fact that the constitution fixes Kazakhstan's multi-ethnic nature and gives an official position to the Russian language as the "language of interethnic communication", one encounters strong feelings among Kazakhs that this does not correspond with their view on the ethnic and linguistic situation in the country.

As one of my Almaty colleagues said, "it is the duty of every Kazakh to visit Turkestan at least once in their lifetime". Nevertheless, she was also very critical of what the state has turned the pilgrimage site into. It is not very unusual to encounter an opinion among more conservative Kazakhs that Turkestan is 'too touristic'. For them, the 'real' pilgrimage site is the mausoleum of Arystan Bab, the teacher of Kozha Akhmet Yasaui, located half way between Shymkent and Turkestan. Turkestan is, according to that more conservative view, a 'built space' (Casey 1997: 309) where a well organised and luxuriously built compound decreases the sacral authenticity of the site. Arystan Bab's mausoleum, with its non-renovated buildings and wells of holy salty water corresponds more with the idea of a sacred pilgrimage site. The international profile of visitors, quotes of Nazarbayev at the entrance of Kozha Akhmet Yasaui's mausoleum, and the lack of Russian on the signs, hints that the state wants to deliver a certain message with Turkestan. Religious Kazakhs seem to be right because Turkestan has been converted into an 'other space' in the Foucauldian sense, where the political meaning dominates the religious. The message is that Kazakhstan is a legitimate state with several centuries of history. The downplaying of Russian strengthens this message. The architecture of the compound and choice of languages signals that the Kazakh state is part of the Muslim Turkic world and belongs to, by definition, Central Asia. In this way the Kazakhs and their state are legitimised and anchored in what many people call the Muslim or Turkic civilisation. 
In general, one can argue that this is the message that both foreign pilgrims and Kazakhs want to hear.

Turkestan used to be a town with an Uzbek majority. Currently Kazakhs are the majority (40\% of population) but Uzbeks consist of the largest minority, approximately one third of the town's population. For many of my Astana and Almaty colleagues, Shymkent and Turkestan are the 'deep south', too backwards and too Uzbek. This opinion, as a rule, changes when people visit the region and see that the lifestyle is not much different from the way people live in the northern regions of the country. The pilgrimage site is, nevertheless, a strong national symbol. It is interesting to observe how ethnic Kazakhs perceive the Uzbek influence of the region when it comes to the pilgrimage site. As former nomads and nationals of the most successful Central Asian state, Kazakhs have certain prejudices towards Uzbeks, who are traditionally agriculturalists and provide cheap migrant labour within Kazakhstan. Without any doubt, Uzbeks have contributed to creating the conservative religious reputation of Kazakhstan's southern regions. It is believed that Uzbeks are more conservative and religious, hence the large number of beautiful mosques in Shymkent and Turkestan. The image of the 'traditionalistic' south has, however, been 'nationalised' in popular perception and the region is often seen as a 'genuine' Kazakh counterweight to Russified northern Kazakhstan, where Soviet architecture dominates, the Soviet era economy is still apparent, and where a large proportion of the local Kazakh population has changed to speaking Russian. The meaning of the Turkestan pilgrimage site with the graves of Kazakh khans has gained political importance as proof of the long history of the Kazakh nation. In a paradoxical way the pilgrimage site merges religion with nationalism, emphasising the importance of Islam in the modern Kazakh identity, something that contradicts the official rhetoric and politics that attempts to depict Kazakhstan as a secular multi-ethnic state. This is the discrepancy that one encounters in Kazakhstan almost everywhere. One sees billboards hailing Kazakhstan as a nation of the Great Steppe next to other billboards depicting interethnic friendship in the country. The salient message of the state's interest in its sacred geography is to make clear that Kazakhstan is a Kazakh country where everybody is welcome, but where non-Kazakhs should acknowledge their status as guests.

Aimar Ventsel

(University of Tartu)

\section{References}

Aitken, Jonathan. 2009. Nazarbayev and the Making of Kazakhstan. London; New York, NY: Continuum.

Casey, Edward S. 1997. The Fate of Place: A Philosophical History. Berkley, MI; Los Angeles, CA; London: University of California Press.

Cummings, Sally N. 2009. Inscapes, Landscapes and Greyscapes: The Politics of Signification in Central Asia. - Europe-Asia Studies 61 (7): 1083-1093. DOI: https://doi. org/10.1080/09668130903068616.

Dave, Bhavna. 2007. Kazakhstan: Ethnicity, Language and Power. London, New York, NY: Routledge. DOI: https://doi.org/10.4324/9780203014899.

Hann, Chris and Mathijs Pelkmans. 2009. Realigning Religion and Power in Central Asia: Islam, Nation-State and (Post)Socialism. - Europe-Asia Studies 61 (9): 1517- 1541. DOI: https://doi. org/10.1080/09668130903209111.

Hiro, Dilip. 1994. Between Marx and Muhammad: The Changing Face of Central Asia. London: Harper Collins.

Osharov, Roman. 2014. Putin o Kazakhstane: “U kazakhov ne bylo gosudarstvennosti". - Golos Ameriki. https://www.golos-ameriki.ru/a/ putin-about-kazahstan-osharov/2434090.html (accessed November 6, 2019). [Ошаров, Роман. 2014. Путин о Казахстане: «У казахов не было государственности». - Голос Америки. https://www.golos-ameriki.ru/a/putin-aboutkazahstan-osharov/2434090.html.]

Roy, Olivier. 2000. The New Central Asia: The Creation of Nations. London: I. B.Tauris. 